New Zealand journal of industrial relations. 1986. 11. 149-159

\title{
ARTICLES
}

\section{Breakaway unions: an Australian case}

\author{
Julian Teicher*
}

This paper examines the concept of breakaway unions and places it within the Australian institutional context. The concept is then applied to a particular case involving power station operators, a group of which seceded from one union and merged with another while retaining their group autonomy. This somewhat novel approach to circumventing the constraints of registration under the Conciliation and Arbitration Act highlights the limitations of industry style unions in representing a diverse membership.

\section{Introduction}

Although Australia has a large number of unions this does not imply that workers have the right to choose between unions or to create unions of their own choosing. At the federal level the legislative framework is specifically designed to minimise duplication of union coverage. The vehicle whereby this object is achieved is the process of federal registration. Registration entails an attempt to vest unions with mutually exclusive coverage rights with the boundaries between unions usually being defined in occupational terms. The principal attractions of registration are threefold. First, unions are freed from the necessity to engage in costly and difficult struggles with employers for recognition. Having gained recognition, however, a union cannot compel an employer to negotiate. Second, if negotiations are unsuccessful a union can activate the processes of compulsory conciliation and arbitration with the outcome (award) being legally binding. ${ }^{2}$ Third. registration implies that employees are unlikely to be able to exercise a choice between unions, thereby guaranteeing registered unions a core membership and an associated revenue flow. This may be further augmented as a result of various union security devices arrived at through arbitral processes or collective negotiations.

The protection afforded to registered unions from competitors and antagonistic employers is not only a major attraction of federal registration; it is a key reason for the continued existence of a large number of unions (Howard, 1980, pp 84-89). Hence, in 1979, there were 328 unions with the number falling to 319 in 1983 and rising to 329 in 1984. At December 1984, 149 of these unions were federally registered and they represented 82 percent of all union members (Australian Bureau of Statistics, 1984). Significantly, the numerical dominance of federally registered unions has been achieved despite the disinclination or failure of successive industrial registrars to define exclusive coverage rights for registered unions. Indeed. it has been suggested (Howard. 1980, pp 86) that the early industrial registrars sometimes exercised a discretion not to grant exclusive rights of coverage in order to effect one of the major objectives of the Conciliation and Arbitration Act: "to encourage the

* Lecturer in industrial relations. Monash University. Australia.

1 In principle. both industry and occupational unions are registerable. however. in practice. most registered unions are of the occupational type. An organisation's eligibility or constitution rule is the principal source of its capacity to recruit and represent the industrial interests of members. An organisation's industry rule tends to reinforce the coverage specified in the eligibility rule. See $R v$. Dunlop Rubber Australia \& Ors: ex parte Federated Miscellaneous Workers Union (1957).

2 The practical significance of this lies chiefly in the capacity of unions to secure adherence to the terms of an award rather than the near moribund penal provisions relating to award breaches by unions. 
organisation of representative organisations of employers and employees and their registration under the Act". In part the duplication of coverage rights also reflects Australia's inheritance from Britain of a structure of craft and occupational unions overlaid with a number of large conglomerate occupational unions. That is, over time technological and organisational changes have produced further overlaps in union coverage rights as some skills vanish and others are created. For example, in the shipbuilding industry the shift from timber to metal construction produced a longstanding demarcation dispute between shipwrights and boilermakers.

The nature of the registration process is also central to the subject of breakaway unions. As commonly understood a union breakaway is constituted by the secession of a minority interest group which feels unable to exercise an influence on union decision making commensurate with its perception of its sectional status and potential strength (Turner, 1962, p 265). Typically such minorities are defined in terms of occupation or skill and, almost by definition, occur in large unions with a heterogeneous membership. In respect of conglomerate occupational unions Lerner (1961, p 191) stresses the importance of occupational groups being "able to influence decisions affecting their own occupation". This may be difficult to achieve in practice, because the impetus to maintain established relativities means decisions relating to one group impact on most others. Whether a breakaway occurs, however, depends on a variety of factors. some of which are conditioned by the Australian system of union registration. Usually a breakaway will be strongly opposed by employers and the relevant union. Employers recognise that breakaways will almost inevitably pursue improved wages and conditions more aggressively than established unions. Recognition of a breakaway would also provoke industrial retaliation from other unions and a deterioration of normal industrial relations processes. Furthermore the nature and extent of union security devices would affect the capacity of a breakaway to recruit members and achieve a financially viable size. The position of a breakaway union is further complicated by the registration process which enables a registered union to oppose an applicant on, among other things, the grounds that "an organisation to which the members of the association might conveniently belong has already been registered". Although the objectors may ultimately fail, their opposition can succeed indirectly by necessitating a costly and prolonged series of legal proceedings which few newly formed organisations would have the resources to withstand.

The institutional features discussed above are important influences on the conduct and character of Australian unions. The prominence of arbitral proceedings and the extensive statutory regulation of union conduct tends to produce organisations which are highly centralised. Dispute settling and award making devolve toward full-time officials with shop floor organisation typically remaining undeveloped. There are notable exceptions like the Amalgamated Metal Workers Union and the Building Workers Industrial Union (Davis, 1977, pp 357-60: Davis, 1983, pp 212-14). Generally a number of unions will have coverage rights in a particular industry and in respect of a particular group of workers these rights may overlap. Two possibilities flow from this: workers have a choice of union or the overlap is a source of inter-union conflict. In the latter case, dual union membership is a solution sometimes adopted. Commonly, federal registration and union security arrangements combine to deny workers a choice of union and may imply membership of a union in which their interest is a minority view. It is argued above, however, that there is little scope for such a group to secede and form a federally registered union. An alternative is to merge with an existing union as occurred in the Victorian power industry.

In the Victorian power industry there is a multiplicity of unions although. for the most part. a worker's classification precludes any choice of union. Power station operators are the exception with the Australian Institute of Marine and Power Engineers (AIMPE), the Federated Engine Drivers and Firemen's Association (FEDFA) and the Municipal Officers

3 In 1974 the 2 unions concerned. the Federated Shipwrights and Ship Constructors Association and the Amalgamated Metal Workers Union, amalgamated but it is not clear whether the demarcation line continues within the merged union.

4 The words of section 142 of the Conciliation and Arbitration Act refer to the convenience of the Conciliation and Arbitration Commission in fulfilling its statutory function of preventing and settling disputes and not the convenience of a particular union or the Industrial Registrar. See Australian Railways Union v. National Union of Railwaymen of Australia (1933). 
Association (MOA) having overlapping coverage rights. ${ }^{5}$ In practice there was little effective choice until the late 1970 s. Historically. AIMPE was only marginally involved in the power industry, providing continuing representation for ex-marine engineers: MOA has provided representation for a heterogeneous range of "staff" (white-collar) classifications and FEDFA represented a similarly diverse range of "wages" (blue-collar) classifications. Through its Staff Sub-branch FEDFA also represented the lower ranks of the operator classifications, having exclusive coverage of unit attendants. but it has generally failed to recruit at the staff level. This led to the vast majority of operators joining the MOA. Over time. the MOA's stance on a number of issues. led many operators to view it as unrepresentative of their interests. FEDFA. as a union predominantly representative of wages employees, was equally unacceptable. AIMPE, however, offered a solution which enabled participation in the federal industrial relations system without the limitations inherent in holding a minority view. Although federally registered. AIMPE offered the operators organisational autonomy through the creation of a Latrobe Valley Sub-branch with membership restricted to the supervisory group in the State Electricity Commission of Victoria (SECV) of which the operators were a major component.

The circumstances surrounding the creation of a breakaway union. which circumvented the constraints imposed by Australia's national industrial relations system. is the subject of this paper. The exposition proceeds in 2 stages: an examination of the sources of dissatisfaction of the operators and an account of 2 almost identical disputes which were central to the occurrence of a breakaway.

\section{Determinants of militancy among the operators}

The SECV power station operators are staff labour and as such have traditionally received superior conditions of employment to most other SECV employees. In turn they are expected to exercise high levels of skill and responsibility. being charged with the safe operation. maintenance and repair of the complex and volatile equipment constituting a power station. Notwithstanding their special position. the operators have exhibited an orientation to unionism and an industrial militancy which is surprising at first sight. There is. however, a growing literature directed to explaining this phenomenon (for example. Griffin, 1985). The factors which appear to be central to the present case are the strategic location and the relative deterioration in the wages and conditions of the operators.

The technological and social organisation of power stations has meant that operators are well placed for engaging in industrial action. While the imposition of work bans has immediate and drastic consequences. such action is readily reversible if confined to reductions in generating load. Over time this leverage has been enhanced by the increasing capacity of generating units. Until 1961, the largest generating set in the Latrobe Valley was 20 megawatts but the commissioning of Yallourn $E$ in that year increased this figure to 120 megawatts. The commissioning of Hazelwood Power Station between 1962 and 1969 brought on stream 8 generating units of 200 megawatts. This was followed by the commissioning of the Yallourn W power station with 2350 megawatt units and 2375 megawatt units. Most recently. in 1984, the first of 4500 megawatt units were commissioned at the Loy Yang power station. As power stations become larger and more technologically advanced the electricity supply system is rendered more vulnerable to industrial disruption. This vulnerability is further increased by the gradual centralisation of generating capacity in the Latrobe Valley.

These technological factors are complemented by the skill specificity of the operators. For example. because Hazelwood power station was commissioned over a number of years, the control rooms of the 8 units differ substantially and most operators are qualified in relation to a particular unit. Likewise. operators cannot shift from one power station to another without further training. Typically, however, operators remain SECV employees for a major portion of their working lives. being trained and retrained for successively higher positions or other positions at a similar level. The low substitutability or skills specificity of the operators

5 For a more detailed discussion of the 1 arious unions involved in the power industry see an earlier paper by the author (Teicher. 1980. pp 316-20).

6 The notion of a series of alternative forms of expressing industrial conflict is common in the sociological literature on industrial relations: see for example R Hyman (1972 p 57). 
contributes significantly to their strategic position. This was graphically illustrated during the 1980 shiftwork dispute when the Victorian Government announced it would invoke the Essential Services Act enabling deployment of non-SECV labour to operate the power stations: the Government later conceded this was not feasible (Australian, 1980, 1). An important corollary of the operators' skill specificity is that labour turnover does not provide an alternative to overt expressions of industrial conflict. Thus, survey findings suggest that operators perceive themselves as trapped into SECV shift work but this perception partly reflects both reliance on penalty payments to augment family income and the absence of promotional prospects. In their response to a 1982 survey questionnaire, 72 percent of shiftworkers believed it would be difficult or impossible to get a transfer to daywork but only 11 percent had ever applied for a transfer. Among shiftworkers at large. 74 percent would transfer to daywork if they could obtain equivalent pay. In the staff classifications only 29 percent reported having received promotions compared to 43 percent of dayworkers (Greenwood. 1982, p 63).

The technological and organisational features of the power stations endow the operators with considerable bargaining power. Significantly, the probability of it being exercised is increased by the organisational features of power stations. First, because of technological advances the duties of the operators are increasingly centred on vigilance with fewer directly operational tasks performed. Periods of activity are closely related to malfunctions, indicated by sophisticated alarm systems, or routine maintenance. Thus, there are typically long periods of passive working time. Second, the operators in each control room of the unitised power stations. Hazelwood, Yallourn W and now Loy Yang. constitute a small team; for example, at Hazelwood power station there are 2 generating units for each stage and the team is composed of 2 unit controllers, 4 assistant unit controllers and 4 unit attendants. Third, because of the erratic and inconvenient hours of work shiftworkers tend to have very restricted family and social lives. In the Latrobe Valley, with the exception of immediate family, shiftworkers' social relationships are mostly confined to fellow SECV shiftworkers. This contention receives some support from recent findings that 27 percent of shiftworkers reported "most or all of their friends" were shiftworkers and this percentage increased with age (Greenwood. 1982, p 64). Insofar as these friends are co-workers it is expected that perceptions formed in the workplace will be reinforced.

Thus. it may be concluded that the organisational features of power stations reinforce the social cohesion of the work group and facilitate expression of grievances. Moreover, there are few groups of SECV employees as strategically placed as the operators to disrupt electricity supplies. Such is the power of the operators that in the 1980 shiftwork dispute, industrial action brought immediate power restrictions. By contrast in the 11 -week maintenance workers strike of 1977 restrictions were not imposed until the latter stages of the stoppage (Benson and Goff. 1979, p 225). Despite their strategic location, the operators were industrially quiescent until 1976. The immediate causes of the transformation were the erosion of wage relativities in a period of rapidly rising wages and extension of staff employment conditions to the wider SECV workforce. Related to these was the apparent failure of the MOA to represent adequately the industrial interests of the operators. This latter point is discussed extensively in the following section.

Two events in the recent history of Australian wage fixation are central to the deteriorating wage relativity of the operators: the introduction of the minimum wage-total wage concept in 1967 and the establishment of the system of national wage indexation in 1975. The motivation of the Conciliation and Arbitration Commission in both cases was similar, to curtail an accelerating rate of wage inflation. By the 1960 s the basic wage had ceased to be a true minimum wage and was a major part of all award wage rates, hence limiting the Commission's capacity to increase the wages of the lowest paid with minimal inflationary consequences. The creation of the minimum wage was designed to obviate that problem (Niland and Isaac. 1975. p 12). In the buoyant conditions of the 1960s this did not halt the inflationary spiral. Instead it fostered an increased incidence of collectively bargained wage rates. In addition, on occasions the Commission's National Wage Case decisions ruled that equity considerations necessitated recognition of the widespread incidence of over award payments (Hancock, 1975, pp 421-2). Despite this accommodation the Commission had become a vehicle for the spread of wage rises and by the early 1970s National Wage Case decisions operated as a third tier of wage fixation building on industry and local agreements. 
The pattern of wage fixation in the period preceding the introduction of wage indexation in 1975 is reflected in wage movements and relativity changes in the SECV. In September 1970 the wage relativity between a base grade fitter and a representative operator classification was 51.3 percent and thereafter it generally increased reaching 53.9 percent immediately prior to the introduction of wage indexation in April 1975. During the period 1972-1974 erosion of the fitter-operator relativity occurred due to National Wage Case decisions resulting in increases which were flat rate or had a flat rate component. In addition, in November 1974, a $\$ 9$ movement in the Metal Trades Award flowed into the operators award as a flat rate increase. The compression of relativities was further exacerbated by the introduction of the State Incremental Payments Scheme (SIPS) in 1972 which increased the over award payments of manual grade employees by $\$ 4.50$, that is, from 9.8 to 11.4 percent of an Assistant Unit Controller's minimum wage rate. ${ }^{8}$ The resultant relativity compression has generally been maintained through subsequent adjustments to SIPS because the operators are covered by a paid rates and not a minimum rates award. Still further deterioration in the relative position of the operators occurred following the Commission's departure from full wage indexation in its National Wage Case decisions beginning with the March quarter 1976 and ending with the December quarter 1977. Flat rate increases which were integral to plateau indexation brought a 2.4 percent increase in the fitter's relativity to 56.3 percent in a period which corresponds with the shiftwork dispute of 1976-77.

The pressure placed on the operator's relative position by metal industry wage movements. increased over award payments, and National Wage Case decisions, was exacerbated by actual and impending changes in employment conditions. Dissatisfaction with continuing differentials between staff and wages employees was reflected in a log of claims prepared by Latrobe Valley shop stewards in January 1977. Along with increased wages, they demanded that conditions of employment of wages employees be increased to achieve parity with staff employees (Benson and Goff. 1979. p 221). Later that year the failure of negotiations resulted in a prolonged strike by maintenance workers. Although the stoppage brought only minor improvements in wages it set in train a process entailing further erosion of the relative position of operators and other staff. Arguably, the maintenance workers strike was the primary consideration underlying what has been described as the "SECV's desire to move towards uniformity of non wages conditions" (Devries, 1983, p 270). During 1978 there was an improvement in sick leave entitlements and an upgrading of the (Wages) Employees Retirement and Benefit Fund was under consideration. Subsequently there have been improvements in the Retirement Fund and sick leave as well as reductions in hours of work.

The differential conditions of SECV staff and wages employees are evidenced by the fact that the Retirement Fund was not established until 1970 and hitherto wages employees received a gratuity based on years of service. Since 1977 benefits payable from the Retirement Fund have been improved in relative terms. In respect of sick leave entitlements, there has been a progressive narrowing of inequalities and after alterations in March 1980 the only difference between the 2 groups was the entitlement on engagement, 12 shifts for staff and 5 for wages employees. Following the 1980 shiftwork dispute that gap further diminished with wages employees receiving 8 shifts on engagement. Differential hours of work are also a consideration and until 1981 wages employees worked a 40 hour week and staff. a 38.5 hour week. This difference was one that the maintenance workers sought to abolish in 1977, and by early 1980 it had become a principal concern of the Amalgamated Metal Workers Union and other unions representing wages employees. The conduct of this campaign neatly overlaps the 1980 shiftwork dispute, with Latrobe Valley shop stewards receiving reports from officials of the Australian Council of Trade Unions and the Victorian Trades Hall Council on 28 April and deciding to conduct a separate shorter hours campaign from that in Australian industry generally. Detailed negotiations with the SECV commenced in August and resulted in the introduction of a 37.5 hour week/9 day fortnight for all SECV employees in January 1981. Significantly, as the 1980 shiftwork dispute developed. SECV wages employees were turning their attention to a reduced hours campaign which, given the SECV's predilection for uniform employment conditions, would leave the operators relatively worse off.

7 A detailed table showing all wage and relativity movements over a 10 year period to 1980 is available on application to the author.

$x \quad$ SIPS is a flat rate over award payment geared to years of scrvice. It was introduced to enable the Victorian public sector to compete with private employers in attracting and retaining suitably qualified lahour. 
In essence then, the operators were in an excellent strategic position and the unarrested deterioration in their pay and conditions relativity with wages employees provided a strong incentive for exerting industrial pressure. Before they could act effectively the operators needed an effective voice within the MOA or a separate organisational vehicle with which to participate in the federal industrial relations system.

\section{The shiftwork disputes and the formation of a breakaway union}

Without the support of the MOA the operators had limited scope to reverse their deteriorating wages and conditions relativity. The strategy adopted, forming a breakaway union, was not usually open to Australian workers. The AIMPE Latrobe Valley Sub-branch was reformed as a direct result of dissatisfaction with the MOA.

With some 8000 members in the total SECV workforce of 22000 , the MOA is the largest union and has the widest coverage rights of the 24 unions with members in the SECV. The MOA also has overlapping coverage with 2 other unions. the AIMPE and FEDFA. AIMPE has a narrower membership base than either the FEDFA or MOA; its members come from the operator classifications of unit attendant, assistant unit controller. unit controller and charge engineer. This specificity is the result of AIMPE being primarily a maritime union with longstanding links to the power industry. Marine engineers appear to have worked in the power industry since its inception but, despite a continuing membership, AIMPE was inactive in the Latrobe Valley prior to 1977. There appear to be 2 principal reasons for marine engineers remaining AIMPE members on recruitment to the SECV. Historically, the similarity between the technologies employed in the maritime and power industries enabled engineers to be mobile between the 2 industries. Because many engineers moved between seagoing and shore based employment (or wished to retain that option) they retained AIMPE membership, without which employment on coastal or Australian flag overseas shipping was unobtainable (Buckley, 1970, pp 113-15 and 183-4). Additionally, during the 1960s. the commissioning of the giant Hazelwood power station led to an unprecedented increase in labour requirements. The shortfall was met by recruitment from the United Kingdom power industry and among marine engineers. Both groups were reportedly reluctant to join the State Electricity Commission of Victoria Officers Association (SECVOA), the predecessor to the MOA SECV Branch (Lyon, 1983, p 2). Instead the operators sought to join narrowly-based unions for technical personnel as occurred in the UK power industry and the Australian maritime industry. Dissatisfaction with the broad coverage of the SECVOA and AIMPE's failure to represent its SECV members were reflected in requests for AIMPE to establish an award for operators (AIMPE, 1963). These sentiments led to the formation of the Latrobe Valley Sub-branch of AIMPE in 1964. Award coverage was achieved by default the following year when, as a union with members in the SECV. AIMPE became a party to the Municipal Officers Association (SECV) Award 1965. Thus. the AIMPE Sub-branch was formed to provide separate representation for the operators but was paradoxically tied into an industry award from the outset. In the ensuing years the AIMPE Sub-branch dwindled in numbers and activity levels, and the MOA continued to represent the majority of the operators despite continuing dissatisfaction. A former member and activist in both AIMPE and MOA has observed:

The MOA made considerable gains for their members in the late 1960s and early $1970 \mathrm{~s}$ and the industrial muscle of the staff shiftworker was used to help make these gains. however a lot of these gains did not go to the shiftworkers (Lyon. 1983. p 3).

In 1976, following pressure by the operators, the MOA served claims on the SECV seeking improved shiftwork conditions. The major claims were: increased shift premiums, week-end and overtime penalties; inclusion of all allowances and penalties in overtime calculations; increased annual leave and optional early retirement with full benefits for shiftworkers. The claims were rejected with 2 minor exceptions. Combined meetings of AIMPE. FEDFA and MOA responded to this with an ultimatum that if a "satisfactory answer is not received by 7/1/77 a further meeting will be convened to consider direct action" (MOA, 1976). The SECV discounted the threat as "executive generated with the support of a few militants" (SECV. 1976). In January 1977, the operators met again and decided to hold a 24 hour strike followed by work bans. On its own motion the Conciliation and Arbitation Commission attempted to 
settle the dispute by putting forward a 3 point proposal: a private arbitration, the parties waive their rights to formal proceedings including appeals and deferral of industrial action. Industrial action seemed inevitable following the SECV rejection of this proposal. However. when the MOA Latrobe Valley shiftworkers met in February 1977 they voted to "defer" the stoppage but brought forward the imposition of bans (MOA. 1977a). Although the deferral may have been based on tactical considerations at least some of the operators perceived it as a betrayal by the MOA (Lyon. 1983, p 3). The imminence of bans led the Arbitration Commission to convene a private conference to consider a revised settlement proposal. Again MOA acted indecisively and would have accepted the diluted settlement proposal. but the SECV remained intransigent seeking arbitration of all claims. This obduracy highlighted the indecisiveness of the MOA leadership and acted as a catalyst for the secession of the militant operators. Following the failed settlement proposal. a meeting of MOA shiftworkers voted to "recommend a 48-hour stoppage of shiftworkers to the MOA Executive" in protest (SECV. 1977a). Despite this resolution the Branch Executive opted to unconditionally lift the bans and rejected further industrial action (MOA. 1977b). This position was also adopted by FEDFA. By now the operators isolation was nearly complete: both their views and industrial power had been ignored again.

Following an SECV application the shiftwork claims were arbitrated by a full bench of the Arbitration Commission which rejected them. Responding to the decision. the MOA SECV Branch Secretary predicted "a virtual shut down" of the Latrobe Valley power stations. however. a meeting of members was not convened until 15 June. 11 days after the decision was handed down (ABC National News. 1977). At this meeting the MOA Committee of Management recommended that members:

take account of the current political and economic climate. in deciding any future course of action and to be aware the extreme course of direct action necessary to overturn the full bench decision could lead to the complete isolation of the union by the forces presently pursuing a course designed to destroy the trade union movement (MOA. 1977c).

A number of the operators instead argued for an immediate indefinite stoppage to force the SECV to revise its position. Arguably, the MOA had a responsibilty to caution members regarding the possible consequences of strike action. especially in a critical industry such as electricity generation. however, its advice was tantamount to outright opposition. The dire warnings of the officials succeeded in that a motion proposing a national power industry campaign and a report back meeting "to consider progress made and the need for direct action" was adopted by a narrow majority (SECV. 1977b). This marked a further stage in alienating the operators from other MOA shiftworkers and its broader membership: it was a turning point in the formation of a breakaway union. For the first time there was a public expression of the necessity to form a separate union for shift staff. Also it was reported a number of Hazelwood Power Station operators left the meeting in protest at the resolution (SECV. 1977b).

The MOA response to the full bench decision had completed the industrial isolation of the operators. The proposed national campaign was seen as a diversion to further postpone industrial action, as it followed 6 months during which the MOA forestalled action designed to "help speed up proceedings and to show the full bench the Membership (sic) was keen to improve their conditions" (Lyon. 1983. p 3). Moreover. the multiplicity of unions in the power industry and their preoccupation with various other issues such as shorter hours. combined with the absence of a history of joint national action. suggested the proposed campaign was doomed to failure. Indeed. these were just the sort of considerations underlying the formation of a breakaway union. Predictably. during 1978 MOA came no closer to a national campaign than meeting with its interstate branches to draft a national shiftwork log of claims and meetings with other unions further evidenced the impracticality of a national campaign. One crucial obstacle was that in New South Wales and Queensland the industry was not regulated by federal awards and those branches (state registered unions) were reluctant to cede their autonomy, albeit in a limited way.

Thus. over the period 1976-78. events reached a stage ripe for the formation of a breakaway union. Consequently. and after some discussions among the operators. AIMPE was requested to reform the Latrobe Valley Sub-branch and allow the staff shiftworkers to "run their own union affairs with the help of a full-time official" (Lyon. 1983. p 4). AIMPE accepted this proposition and in effect did what few other unions have done - granted operational 
autonomy to a group of members. For the most part Australian unions attempt to limit branch autonomy whereas the AIMPE Sub-branch was given such latitude that it could embark on industrial action without approval from the State or Federal levels of the union. The concession of Sub-branch autonomy may have been a pragmatic attempt to offset a dwindling in membership and revenue occasioned by the decline of the Australian maritime industry (Melbourne Sun. 1980, p 46). In any case this mode of operation was not unfamiliar to AIMPE with its far flung membership at sea being left to run their own affairs for long periods of time. The reformed AIMPE Sub-branch moved quickly to recruit Latrobe Valley operators by tapping discontent among MOA members. It emphasised that in representing a restricted range of classifications the interests of one group would not be sacrificed to "the veto of large groups of members in other positions, i.e. trade offs, back downs and other compromises being made so as to protect the interests of persons not connected with shift operations" (AIMPE, 1977a). This was an unsubtle reference to MOA convened meetings of shiftworkers where the operators were outvoted by dayworker staff.

Meetings of power industry unions continued during 1979 but lack of support for a national campaign resulted in a decision to restrict action to Victoria." By the end of the year MOA was in a similar position to 1976; it was about to serve a log of claims on behalf of shiftworkers but this was to be a joint unions campaign focusing on AIMPE. FEDFA and MOA. This time around there was one fundamental difference: AIMPE had recruited strongly among the disaffected operators and the breakaway union represented the majority of unit controllers, assistant unit controllers and charge engineers at the unitised power stations. The secession and formation of the AIMPE Sub-branch meant the operators views had to be explicitly accounted for. Hence. AIMPE initially made its participation conditional on inclusion of a claim for earnings-related shift premiums, not just an increase in the existing flat rate shift premiums. Subsequently AIMPE revised its position to include a flat rate component but the MOA rejected this as it did not contain a minimum payment to protect the earnings of lower classifications (AIMPE, 1979).

In early 1980 AIMPE was the only union keen to proceed with a shiftwork log of claims; the FEDFA and MOA were preoccupied with other industrial issues. The consequences of the resurrection of the AIMPE Sub-branch now became evident. The Sub-branch was pressing the Victorian Branch officials to serve the claims and unilaterally undertake an industrial campaign. AIMPE responded and served the log on 2 April, only to be followed by MOA 2 weeks later. Having pre-empted the other unions AIMPE indicated to FEDFA and MOA that it still favoured a joint campaign. In any case the claims served on the SECV were almost identical to the joint unions log formulated in 1979. As in 1977 the SECV rejected the claims relying upon its conformity with national standards and the force of the Arbitration Commission decision in the 1976-77 shiftwork dispute (ACAC, 1977). MOA met the rejection by proposing industrial action for late in May and the convening of a combined unions meeting to endorse that action (AIMPE, 1980). The AIMPE Sub-branch Executive rejected a combined unions meeting, referring to the operators' experience of being outvoted in the 1977 dispute. Instead AIMPE again pre-empted MOA by calling a meeting which would precede the MOA meeting and proposing industrial action at Hazelwood and Yallourn W, the 2 stations where the majority of operators were AIMPE members (AIMPE, 1980).

In view of the threatened industrial action the SECV notified the Arbitration Commission of an industrial dispute but proceedings were adjourned on the basis of an MOA submission that it wanted to place new material before the SECV. The AIMPE Sub-branch responded by forestalling industrial action pending the outcome of discussions with the SECV. These discussions were abortive and industrial action was inevitable unless AIMPE resiled from its threats as had the MOA in 1977. The breakaway union was in a different situation, however: the occupational homogeneity of its members and the perceived importance of the shiftwork claims militated against a retreat. The AIMPE Sub-branch met and decided on a (purportedly) indefinite shutdown of Hazelwood and Yallourn W power stations beginning 23 June. A 5 day lead time was provided for MOA to meet and consider participation in the industrial action (AIMPE, 1980). Thus, despite its desire for a joint campaign, the AIMPE Sub-branch continued to force the pace of events in an apparent attempt to fulfill the expectations of its members.

On the eve of the stoppage there were further dicussions with the SECV and a hearing in

9 The shiftwork dispute of 1980 is dealt with only briefly here; for more detail see Teicher (1984. pp 32129). 
the Arbitration Commission. The hearing only highlighted the differences between the AIMPE and MOA and underscored the fact that the other unions representing power industry employees were satisfied with flat rate shift premiums (ACAC. 1980, p 43). Meanwhile the MOA and FEDFA members met in the Latrobe valley and resolved to "support the action of the AIMPE" (ACAC. 1980, p 59). Such was the indirect pressure exerted by AIMPE that the MOA officials shifted from their previous position opposing industrial action to adopting the AIMPE stance of seeking an offer and not simply an agreed settlement procedure (Melbourne Age. 1980, p 9). On the second day of the ensuing 4 day stoppage the MOA convened a combined meeting of shiftworkers but AIMPE refused to participate. Almost by default MOA regained leadership of the dispute resolving to continue the stoppage and extend it to the older Yallourn C. D and E power stations, the main concentrations of MOA operators. The AIMPE had little choice but to adopt this resolution. With the resultant deterioration in power supply. the Arbitration Commission reconvened with the stated intention of referring the dispute to a full bench. The likely unsuccessful outcome of a full bench arbitration of the claims appears to have provided a sufficient stimulus for an already scheduled meeting of unions representing SECV shiftworkers to produce a general formula for resuming work without agreement on the form of shift premiums. This formula. providing for a working party examination of shiftwork. was accepted by the SECV. Although the proposal contained no specific concessions the reference to an operative date and provision for a single Commissioner to decide the shift premium claim were significant if intangible gains when contrasted with events in 1977. Somewhat surprisingly, executive members of the AIMPE Sub-branch, along with FEDFA and MOA officials, agreed to endorse the proposals at a combined unions meeting. This meeting accepted the working party proposal but not without prolonged debate and significant division. Following a resumption of work. proceedings shifted into the working party format and the claims for increased shift premiums and weekend and public holiday penalties were ultimately arbitrated. The claims for increased penalties were refused but shift premiums were increased by 37 percent and the flat rate payment was retained. Despite this the operators could claim that at least their views featured more prominently than hitherto.

\section{Discussion}

In recent years there has been a continuing current of public support for union amalgamations. that is, for a reduction in the number of unions by a process of merger into industry style unions. This advocacy has come from a variety of quarters, employer associations. corporate executives. the Australian Council of Trade Unions, the Australian Labor Party. and government inquiries. Most recently the merger process received strong support in the Report of the Committee of Review into Australian Industrial Relations Law and Systems (Hancock Report). The principal recommendations of the Committee were that. unions with less than 1000 members should be deregistered except in special circumstances. craft or occupational unions be precluded from federal registration in future, and the requirement that a specified proportion of union members must vote for an amalgamation ballot to succeed. be replaced with one defining a majority (Committee of Review. 1985, III.pp 22-24). The Committee further stated there are "too many associations of employees registered and operating within Australia" causing 3 main problems: dissipation of union resources. inter-union conflict and "the difficulties that can arise in the resolution of disputes when employers are obliged to deal with a wide variety of unions, each perhaps with different objectives and expectations" (Committee of Review. 1985. II. p 461).

The continuing existence of a large number of small unions. however, highlights the irrelevance of pro-amalgamation sentiments to the bulk of union members. The situation in the Victorian power industry with a multiplicity of unions is instructive in this regard. The MOA. with coverage rights over a wide range of classifications. was seen as having neglected the interests of at least one group of members. power station operators. Traditionally the operators had received superior wages and conditions of employment to most SECV employees. During the 1970s particularly, their position was undermined. Prior to the introduction of wage indexation in 1975 National Wage Case decisions frequently awarded absolute amounts or contained an absolute component. In addition. increased over award payments received by other employees were not incorporated into the paid rates award of the operators. Further distortion of relativities occurred during the period of wage indexation 
1975-81 when the Arbitration Commission attempted to reduce the wage share in national income by plateau wage indexation. These pressures were compounded by actual of impending improvements in the non-wage benefits received by SECV wages employees.

The operators' dissatisfaction was exacerbated by the MOA's perceived failure to adequately pursue their sectional interests. A crucial episode was the shiftwork dispute of 1976-77 when claims were made on behalf of the operators and their rejection by the SECV resulted in no more than threats of industrial action. The MOA was seen as continuing to neglect the operators when no industrial retaliation followed, rejection of the claims by the Arbitration Commission. This sequence of events resulted in key figures among the power station operators negotiating for a large group of operators to secede from MOA and transfer membership to AIMPE in return for autonomy. The attraction of AIMPE was that as a federally registered union it enabled the operators to participate in the federal industrial relations system without AIMPE exerting any obvious controls over this section of its membership. Indeed, AIMPE recruited on the basis that it would respond to the operators' sectional interests without having to consider the interests of other sections of its membership. Having created a breakaway union the operators used it to pursue their interests while pressuring the MOA into following their lead. This strategy worked reasonably well in the shiftwork campaign of 1980 but the resulting improvements in penalty rates did nothing to redress the operators' declining pay relativity. Notwithstanding, the creation of the Subbranch enabled the operators to occupy a position in power industry industrial relations commensurate with the group's own perception of its importance.

In the final analysis this study highlights the fact that the legalism of the Australian system of industrial relations need not act as a total brake on the formation of unions able to satisfactorily represent sectional interests. It also suggests that even if there are legislative amendments to force and facilitate union amalgamations as recommended in the Hancock Report these may lead to the submergence but not the disappearance of sectional groups. In the operators' case forming a breakaway using a registered union as a vehicle was a solution for a cohesive group of workers who were disgruntled within a conglomerate occupational union. Given the nature of the Australian system it is likely that in most cases the tension will be contained within a union, only occasionally overflowing in wildcat actions.

\section{References}

ABC National News (1977) It's likely the Members of the MOA would stay out for more than 48 hours, transcript, 4 June.

AIMPE (1963) letter from District Secretary to power industry member M Wilson, 29 January.

AIMPE (1977a) Latrobe Valley Sub-branch Notice of Meeting, Circular, circa August.

AIMPE (1977b) Power Industry Shift Penalty Claim, Inter-office memo. 5 October.

AIMPE (1980) Meeting notes of industrial officer, 5 May - 17 June.

Australian Conciliation and Arbitration Commission (1977) State Electricity Commission of Victoria v Municipal Officers Association of Australia, decision, print D3393.

Australian Conciliation and Arbitration Commission (1980) State Electricity Commission of Victoria v Australian Institute of Marine and Power Engineers, transcript, c No 772.

Australian (1980) Fresh stoppage threatens total black-out, 26 June: 1.

Australian Bureau of Statistics (1984) Trade Union Statistics, catalogue No 6323.0.

Benson, J W and Goff, D S (1979) The 1977 Latrobe Valley maintenance workers strike Journal of industrial relations 21 (2) : 217-28.

Buckley, K D (1970) The amalgamated engineers in Australia: 1852-1920 Canberra, Research School of Social Sciences.

Davis E (1977) Decision making in the amalgamated metal workers and shipwrights union Journal of industrial relations 19 (4) : 348-65. 
Davis, E (1983) Participation in six Australian unions Journal of industrial relations 25 (2) : 190215.

Devries. G (1983) Negotiating a shorter working week in the State Electricity Commission of Victoria Journal of industrial relations 25 (1) : 269-85.

Greenwood. K (1982) Survey of rotating shiftworkers in the State Electricity Commission of Victoria. report 1: differences between shiftworkers and dayworkers. Brain Behaviour Research Institute. Latrobe University, mimeographed.

Griffin. G (1985) White-collar militancy Sydney. Croom Helm.

Hancock. K J (1975) The demise of Australian wages policy. In Niland. J R and Isaac. J E (Eds.) Australian labour economics readings Melbourne. Sun Books.

Howard. W A (1980) Australian trade unions in the context of union theory. In Ford, G W. Hearn, J M and Lansbury. R D (Eds.) Australian labour relations readings Melbourne. Macmillan.

Hyman. R (1972) Strikes London. Fontana.

Lerner. S W (1961) Breakaway unions and the small trade union. London. Allen and Unwin.

Lyon. B (1983) The history of the Australian institute of marine and power engineers in the State Electricity Commission of Victoria Gippsland Institute of Advanced Education. unpublished.

Melbourne Age (1980) Strikes located in a precarious state. 26 June. 9.

Melbourne Sun (1980) Shutdown: it's skill a threat. 1 July. 46.

MOA (1976) letter from secretary. SECV branch to SECV. 3 December.

MOA (1977a) Work authority bans imposed: 24 hour stoppage deferred. news release, circa February.

MOA (1977b) Executive decision. SECV branch circular. No 8.

MOA (1977c) Issued by SEC branch MOA. SECV branch circular, circa June.

Niland. J R and Isaac. J E (Eds.) (1975) Australian labour relations readings Melbourne. Sun Books.

Report of the Committee of Review (1985) Australian industrial relations law and systems Canberra. Australian Government Publishing Service. 3 vols.

SECV (1976) Departmental memo, MOA claims - SECV shift workers. 14 December.

SECV (1977a) Record of motions passed at a meeting of Latrobe Valley shiftworkers, 9 February.

SECV (1977b) Note for file. MOA shiftworkers meeting. Latrobe Valley. 22 June.

Teicher. J (1984) Industrial militancy among elite workers in high technology industries: Victorian power station operators Journal of industrial relations 26 (3) : 315-334.

Turner, H A (1962) Trade union growth, structure and policy London. Allen and Unwin.

\section{List of cases}

Australian Railways Union v National Union of Railwaymen of Australia (1933) 32 CLR 443

$R$ v Dunlop Rubber Australia \& Ors: ex parte Federated Miscellaneous Workers Union (1957) 97 CLR 71. 